\title{
KARAKTERISTIK SURIMI BASAH DAN KERING DARI IKAN BARONANG (Siganus sp.)
}

\author{
Ari Wawasto ${ }^{\star}$, Joko Santoso, Mala Nurilmala \\ Departemen Teknologi Hasil Perairan Fakultas Perikanan dan Ilmu Kelautan \\ Institut Pertanian Bogor, Kampus IPB Darmaga, Jalan Agatis, Bogor 16680 Jawa Barat \\ Telepon (0251) 8622909-8622906, Faks. (0251) 8622915 \\ *Korespodensi: ariwwst@gmail.com \\ Diterima: 9 Juli 2018/Disetujui: 25 Agustus 2018
}

Cara sitasi: Wawasto A, Santoso J, Nurilmala M. 2018. Karakteristik surimi basah dan kering dari ikan baronang (Siganus sp.). Jurnal Pengolahan Hasil Perikanan Indonesia. 21(2): 367-376.

\begin{abstract}
Abstrak
Ikan baronang (Siganus sp.) adalah salah satu jenis ikan yang potensial digunakan sebagai bahan baku surimi. Surimi kering adalah salah satu bentuk surimi yang telah mengalami proses pengeringan dan memiliki banyak keuntungan. Tujuan dari penelitian ini yaitu menentukan frekuensi pencucian dan suhu pengeringan terbaik dalam pembuatan surimi kering. Penelitian ini terdiri dari tiga tahap yaitu preparasi bahan baku, pembuatan surimi basah dan pembuatan surimi kering dengan ulangan sebanyak tiga kali. Pencucian dengan dua kali dipilih sebagai perlakuan terbaik dengan derajat putih 50,61\%, protein larut garam 5,27\%, pH 7,07 dan kekuatan gel 1.387,4 g.cm. Suhu pengeringan $60^{\circ} \mathrm{C}$ adalah suhu pengeringan terbaik dengan derajat putih $61,93 \%$, daya ikat air $8,53 \mathrm{~mL} / \mathrm{g}$, protein larut garam 1,96\%, densitas 0,43 $\mathrm{mL} / \mathrm{g}$, kapasitas rehidrasi $2,79 \mathrm{~mL} / \mathrm{g}$ dan stabilitas emulsi $61,09 \%$.
\end{abstract}

Kata kunci: Frekuensi mencuci, ikan kelinci, suhu, surimi kering.

\section{Characteristics of Wet and Dried Surimi from Rabbit fish (Siganus sp.)}

\begin{abstract}
Rabbit fish (Siganus sp.) is one of the fish having highly potential to be used as raw material of surimi. Dried surimi is a form of surimi that has undergone drying process with many advantages. This study aimed to determine the effect of surimi washing frequency and determine the best drying temperature in the manufacture of dry surimi. This study consisted of three stages which were preparation of raw materials, making wet surimi and making dry surimi with three replication. Two times washing treatment was selected as the best treatment, produced surimi with whiteness degree of $50.61 \%$, salt soluble protein of $5.27 \%$, $\mathrm{pH}$ of 7.07 , and gel strength of $1387.4 \mathrm{~g} . \mathrm{cm}$. Drying temperature of $60^{\circ} \mathrm{C}$ was the best drying temperature with water holding capacity of $8.53 \mathrm{~mL} / \mathrm{g}$, salt soluble protein of $1.96 \%$, density of $0.43 \mathrm{~mL} / \mathrm{g}$, rehydration capacity of $2.79 \mathrm{ml} / \mathrm{g}$, and emulsion stability of $61.09 \%$.
\end{abstract}

Keywords: Dried surimi, rabbit fish, temperature, washing frequency.

\section{PENDAHULUAN}

Surimi merupakan konsentrat protein miofibril ikan yang diproduksi melalui beberapa tahapan proses meliputi pemisahan daging dari kulit dan tulang, pelumatan, pencucian, penambahan garam, penambahan cryoprotectant, dan dilanjutkan dengan pembekuan (Balange dan Benjakul 2009; Lanier et al. 2014; Cando et al. 2015). Bahan baku surimi pada umumnya dipilih dari jenis ikan laut yang memiliki daging berwarna putih karena dinilai mampu menghasilkan surimi dengan kualitas gel dan warna yang baik (Park 2014). Spesies ikan yang sering digunakan sebagai bahan baku pembuatan surimi di Indonesia berasal dari ikan ekonomis rendah seperti ikan kurisi, kuniran, swangi, beloso dan gulamah. 
Industrisurimisaatinisedang menghadapi permasalahan terkait ketersediaan bahan baku. Hal tersebut disebabkan oleh Peraturan Menteri Kelautan dan Perikanan No.2 Tahun 2015 yang melarang penggunaan alat tangkap ikan berupa cantrang. Berlakunya kebijakan tersebut berdampak pada sulitnya industri surimi untuk mendapatkan pasokan ikan yang sebagian besar diperoleh dari hasil alat tangkap cantrang.

Pemanfaatan ikan lain sebagai alternatif pengganti bahan baku surimi perlu dikembangkan, terutama dari ikan hasil budidaya. Ikan lele, nila dan patin telah dilaporkan dapat dijadikan bahan baku alternatif pembuatan surimi (Uju et al. 2007; Wijayanti et al. 2014; Hassan et al. 2017). Ikan baronang (Siganus sp.) merupakan salah satu jenis ikan laut yang berpotensi dibudidayakan (Jaikumar 2012; Brandl dan Bellwood 2013). Wahyuningtyas et al. (2017) melaporkan bahwa ikan baronang memiliki potensi besar untuk dimanfaatkan sebagai bahan baku pangan berbasis protein karena memiliki protein yang tinggi $(15,93 \%)$, selain itu karakteristik daging ikan baronang berwarna putih dan memiliki proporsi sebanyak 45,67\%.

Pencucian merupakan tahapan kritis pada proses pembuatan surimi, sejumlah besar air digunakan untuk menghilangkan protein sarkoplasma, darah, lemak dan komponen nitrogen lain yang dapat memengaruhi kualitas dari surimi (Tanuja et al. 2014). Pencucian diketahui dapat meningkatkan konsentrasi protein miofibril serta dapat meningkatkan kekuatan gel dari surimi (Hassan et al. 2017). Uju et al. (2004) melaporkan bahwa pencucian sebanyak satu kali pada surimi ikan jangilus (Istiophorus sp.) mampu meningkatkan kekuatan gel pada produk bakso ikan. Hossain et al. (2004) menyatakan bahwa jumlah siklus dan volume pencucian bervariasi terhadap jenis ikan, kesegaran ikan, tipe alat pencuci dan kualitas surimi yang diinginkan.

Penelitian mengenai surimi terus berkembang, salah satunya yaitu tentang surimi kering. Surimi kering merupakan produk surimi yang telah dihilangkan sebagian besar kandungan airnya dan umumnya berbentuk bubuk. Produk surimi dalam bentuk kering dinilai mampu memberikan lebih banyak keuntungan dibanding surimi basah. Huda et al. (2001) menyatakan bahwa surimikering lebih efisien dalam penyimpanan karena tidak membutuhkan frozen storage, selain itu surimi kering membutuhkan area yang lebih kecil dalam penyimpanan dan mudah dalam pendistribusian.

Penelitian tentang proses pembuatan surimi kering dengan berbagai metode pengeringan telah dilakukan antara lain pengeringan dengan matahari (solar drying), pengering drum (drum drying), pengering oven (oven drying), pengering semprot (spray drying) dan pengering beku (freeze drying) (Santana et al. 2012). Optimasi proses pembuatan surimi kering dari ikan baronang belum dilaporkan, sehingga penelitian ini bertujuan untuk menentukan frekuensi pencucian dan suhu pengeringan terbaik dalam pembuatan surimi basah dan kering dari ikan baronang. Penelitian ini diharapkan dapat memberikan informasi optimasi terhadap karakteristik mutu surimi kering ikan baronang.

\section{BAHAN DAN METODE Bahan dan Alat}

Bahan utama yang digunakan dalam penelitian ini adalah ikan baronang (Siganus sp.) yang diperoleh dari hasil tangkapan laut pada Perairan WPPNRI 712 di Provinsi DKI Jakarta dengan kisaran ukuran $15-22 \mathrm{~cm}$. Bahan lain yang digunakan meliputi cryoprotectant (trehalosa), garam, dan air/ es. Alat utama yang digunakan adalah meat grinder (MK-G1300 P, Panasonic, Osaka, Jepang), cabinet dryer (laboratorium seafast IPB), food processor (Pro Blend Philips) $\mathrm{pH}$ meter digital (Schott Glass Instrument, Jerman), dan texture analyzer (model TATX plus LLOID, Inggris).

\section{Metode Penelitian Preparasi bahan baku}

Ikan baronang dari Muara Angke dibawa ke Laboratorium THP IPB menggunakan styrofoam dengan ditambahkan es dengan perbandingan 1:1 (b/b). Ikan dibersihkan, ditimbang dan dilakukan pemisahan daging dari kulit dan tulang, selanjutnya daging ikan dilumatkan. Daging lumat ikan baronang kemudian diuji komposisi kimianya. 


\section{Pembuatan surimi basah}

Pembuatan surimi basah mengacu kepada Ramadhan et al. (2014). Daging lumat ikan baronang dicuci menggunakan air dingin $\left(10^{\circ} \mathrm{C}\right)$ yang ditambahkan garam sebanyak $0,3 \% \quad(b / b)$. Pencucian menggunakan perbandingan air dan ikan sebesar 4:1 (v/b) dengan frekuensi pencucian sebanyak $1 ; 2$ dan 3 kali. Surimi dari masing-masing perlakuan dianalisis karakteristik fisik dan kimianya meliputi analisis proksimat, derajat putih, $\mathrm{pH}$, protein larut garam, dan kekuatan gel. Pencucian terbaik ditentukan berdasarkan kekuatan gel dan protein larut garam karena dua faktor tersebut merupakan parameter utama penentu kualitas surimi. Surimi dengan perlakuan pencucian terbaik ditambahkan dryoprotectant berupa trehalosa sebanyak $6 \%(\mathrm{~b} / \mathrm{b})$ yang selanjutnya dilakukan proses pengeringan.

\section{Pembuatan surimi kering}

Pembuatan surimi kering mengacu kepada Huda et al. (2012). Surimi basah terbaik dikeringkan selama tiga jam menggunakan cabinet dryer dengan perlakuan suhu 40; 50; 60 dan $70^{\circ} \mathrm{C}$. Setiap perlakuan diuji karakteristik fisik dan kimianya berupa analisis proksimat, derajat putih, daya ikat air, kapasitas rehidrasi, densitas kamba, stabilitas emulsi dan protein larut garam. Suhu pengeringan terbaik ditentukan berdasarkan kandungan air, protein, derajat putih dan stabilitas emulsi.

\section{Analisis proksimat}

Komposisi kimia (kadar air, protein, lemak dan abu) surimi ditentukan dengan metode AOAC (2005), Masing-masing analisis diulang sebanyak tiga kali.

\section{Kekuatan gel}

Analisis kekuatan gel surimi mengacu kepada Balange dan Benjakul (2009). Sampel dalam bentuk kamaboko dengan panjang 2,5 $\mathrm{cm}$ diletakkan di bawah probe berdiameter $\mathrm{Y}$ inchi dengan kecepatan pengukuran 10 $\mathrm{mm} /$ detik, dilakukan penekanan sampel dengan probe silinder tersebut. Kekuatan gel diperoleh dengan mengalikan daya tekan (g) dari alat dengan jarak $(\mathrm{cm})$ sampai potongan kamaboko pecah.

\section{Protein larut garam (PLG)}

Analisis protein larut garam (PLG) mengacu pada Wahyuni (1992). Sampel sebanyak $5 \mathrm{~g}$ ditambahkan $50 \mathrm{~mL}$ larutan $\mathrm{NaCl} 5 \%$, kemudian dihomogenkan dengan waring blender selama 2-3 menit. Sampel disentrifugasi pada $3.400 \mathrm{rpm}$ selama 30 menit, selanjutnya disaring dengan kertas saring Whatman No.1. Filtrat sebanyak $25 \mathrm{~mL}$ dianalisis kandungan proteinnya menggunakan metode semi mikro Kjeldahl.

\section{Daya ikat air}

Pengamatan daya ikat air surimi kering mengacu pada Nopianti et al. (2011), sedangkan pada surimi basah mengacu pada McCord et al. (1998). Sampel dengan berat yang ditentukan disentrifugasi pada 4.500 rpm selama 15 menit, setelah itu supernatan dipisahkan dan bagian padatan ditimbang. Bagian padatan ditentukan kadar airnya dengan mengeringkan dalam oven, sehingga diperoleh berat setelah dikeringkan. Daya ikat air diperoleh dengan cara berat padatan ditimbang dikurangi berat padatan setelah dikeringkan dibagi berat padatan dikalikan $100 \%$.

\section{Derajat putih}

Derajat putih dianalisis menggunakan metode Lanier (1986). Warna gel dari surimi ditentukan menggunakan chromameter $\mathrm{CR}$ 300 (Konika Minolta Jepang). Skala warna yang digunakan untuk mengukur derajat putih adalah L (ligthness), a (redness/greeness) dan b (yellowness/blueness).

\section{Nilai pH}

Analsisi pH menggunakan metode Suzuki (1981). Sampel sebanyak $5 \mathrm{~g}$ ditambahkan akuades $45 \mathrm{~mL}$, kemudian dihomogenkan menggunakan homogenizer selama 2-3 menit. Elektroda yang telah dicelupkan ke buffer standard kemudian dicelupkan ke dalam sampel selama beberapa menit, nilai $\mathrm{pH}$ dibaca setelah menunjukkan angka yang stabil. 


\section{Sifat rehidrasi}

Pengujian sifat rehidrasi mengacu pada Xu et al. (2004). Sampel sebanyak $20 \mathrm{~g}$ dimasukkan ke dalam gelas piala $500 \mathrm{~mL}$, kemudian ditambahkan air sejumlah persen kehilangan air selama proses pengeringan. Sampel diaduk merata hingga menjadi bubur yang kental. Kapasitas rehidrasi dihitung dengan cara membagi selisih berat sampel awal dan akhir dengan berat contoh tepung surimi.

\section{Densitas kamba}

Pengukuran densitas kamba dilakukan menggunakan metode Venugopal et al. (1996). Gelasukur 100mL ditimbang, kemudiansampel dimasukkan ke dalam gelas ukur sampai tanda tera. Densitas kamba merupakan jumlah berat sampel dalam gelas ukur dengan volume $100 \mathrm{~mL}$.

\section{Stabilitas emulsi}

Stabilitas emulsi pada surimi kering di uji dengan menggunakan metode Yatsumatsu et al. (1972). Surimi kering sebanyak 5 g ditambahkan $20 \mathrm{~mL}$ air dan 20 $\mathrm{mL}$ minyak jagung, kemudian dihomogenisasi selama 1 menit. Emulsi dipanaskan di dalam waterbath dengan suhu $90^{\circ} \mathrm{C}$ selama 30 menit, kemudian disentrifugasi pada $7.500 \mathrm{rpm}$ selama 5 menit. Stabilitas emulsi dihitung dengan cara membagi volume emulsi setelah disentrifugasi dengan volume awal, kemudian dikalikan 100.

\section{Analisis data}

Data hasil penelitian diolah menggunakan software IBM SPSS Statistics 23. Data penelitian dianalisis dengan uji ragam menggunakan rancangan percobaan acak lengkap satu faktor, dengan tiga kali ulangan, serta menggunakan uji lanjut Tukey.

\section{HASIL DAN PEMBAHASAN Karakteristik Surimi Basah}

Hasil uji lanjut Tukey menunjukkan bahwa frekuensi pencucian berpengaruh terhadap perubahan proksimat surimi basah (Tabel 1). Kadar air pada surimi mengalami peningkatan seiring bertambahnya frekuensi pencucian, sedangkan kadar protein dan lemak mengalami penurunan. Hasil ini juga didukung oleh penelitian Hassan et al. (2017) bahwa bertambahnya frekuensi pencucian menyebabkan peningkatan terhadap kadar air dan menurunnya kadar protein serta lemak. Karthikeyan et al. (2006) menyatakan bahwa meningkatnya kadar air pada surimi selama pencucian disebabkan oleh proses hidrasi protein miofibril, dimana komponen air berdifusi ke dalam matriks protein miofibril. Proses pencucian juga berpengaruh terhadap penurunan kadar protein surimi basah yang disebabkan oleh hilangnya protein larut air (sarkoplasma) selama proses pencucian dan meningkatnya kadar air di dalam produk akhir Ismail et al. (2010). Lemak pada surimi sebagian akan mengapung di atas permukaan air dan hilang bersama proses pencucian, sehingga akan menurunkan kadar lemak pada surimi basah (Suvanich et al. 2000).

Derajat putih merupakan salah satu atribut awal dalam penilaian fisik surimi. Frekuensi pencucian memberikan pengaruh nyata terhadap peningkatan derajat putih surimi (Tabel 2). Nilai derajat putih terbaik terdapat pada pencucian kedua dan ketiga karena tergolong ke dalam kategori surimi kelas I. Lanier (1992) menyatakan bahwa syarat derajat putih pada surimi kelas I adalah lebih dari 46\%. Chaijan et al. (2004) menyatakan bahwa proses pencucian dapat meningkatkan derajat putih pada surimi. Hassan et al. (2017) melaporkan bahwa derajat putih surimi ikan patin meningkat setelah dilakukan empat kali pencucian yaitu dari 44,39 menjadi 73,38 . Peningkatan derajat putih pada surimi disebabkan oleh terbuangnya pigmen, darah dan kotoran lain ketika dilakukan proses pencucian.

Perubahan nilai $\mathrm{pH}$ dapat memengaruhi sifat jaringan ikat pada daging. Nilai $\mathrm{pH}$ dapat menyebabkan terdenaturasinya protein miofibril, sehingga akan berakibat buruk pada pembentukan gel surimi. Nilai $\mathrm{pH}$ yang baik untuk pembentukan gel surimi adalah netral atau sedikit basa (Kang et al. 2009). Hasil pengamatan menunjukkan bahwa proses pencucian mampu meningkatkan nilai $\mathrm{pH}$ pada surimi ikan baronang (Tabel 2). Nilai $\mathrm{pH}$ surimi ikan baronang yang dihasilkan melalui pencucian dua hingga tiga kali 
Tabel 1 Komposisi proksimat surimi basah

(Table 1 Proximate composition of wet surimi)

\begin{tabular}{ccccc}
\hline \multirow{2}{*}{$\begin{array}{c}\text { Frekuensi } \\
\text { pencucian/ } \\
\text { Washing cycle }\end{array}$} & Air/ Moisture & $\begin{array}{c}\text { Protein/ } \\
\text { Protein }\end{array}$ & Lemak/ Fat & Abu/ Ash \\
\cline { 2 - 5 } & & $19.14 \pm 0.76$ & $1.17 \pm 0.26$ & $0.54 \pm 0.14$ \\
\hline $\begin{array}{c}\text { Daging lumat/ } \\
\text { Mince fish }\end{array}$ & $78.59 \pm 0.75$ & $16.57 \pm 0.37^{\mathrm{a}}$ & $1.04 \pm 0.11^{\mathrm{a}}$ & $0.50 \pm 0.01^{\mathrm{a}}$ \\
\hline 1 & $81.49 \pm 0.32^{\mathrm{b}}$ & $15.49 \pm 0.24^{\mathrm{b}}$ & $0.83 \pm 0.05^{\mathrm{b}}$ & $0.45 \pm 0.03^{\mathrm{a}}$ \\
\hline 2 & $82.74 \pm 0.30^{\mathrm{a}}$ & $15.74 \pm 0.12^{\mathrm{b}}$ & $0.83 \pm 0.07^{\mathrm{b}}$ & $0.40 \pm 0.07^{\mathrm{a}}$ \\
\hline 3 & $82.55 \pm 0.15^{\mathrm{a}}$ & & & \\
\hline
\end{tabular}

mampu menghasilkan $\mathrm{pH}$ surimi yang netral. Kisaran $\mathrm{pH}$ tersebut dapat digolongkan ke dalam $\mathrm{pH}$ yang baik untuk produk surimi. Hasil yang sama juga dilaporkan oleh Asgharzadeh et al. (2010) bahwa $\mathrm{pH}$ pada surimi ikan mas meningkat seiring dengan bertambahnya frekuensi pencucian, yaitu meningkat dari 7,0 menjadi 7,8 setelah satu kali pencucian. Suvanich et al. (2000) menyatakan bahwa meningkatnya nilai $\mathrm{pH}$ setelah dilakukan pencucian disebabkan oleh larutnya sebagian asam amino bebas, asam lemak bebas, asam laktat dan komponen lain yang bersifat asam.

Protein larut garam atau miofibril merupakan protein yang berperan penting dalam pembentukan gel surimi dan merupakan salah satu parameter utama untuk menentukan mutu surimi pada penelitian ini. Hasil analisis menunjukkan bahwa kadar protein larut garam meningkat seiring bertambahnya frekuensi pencucian (Tabel2). Hasilini juga sesuai dengan penelitian Hassan et al. (2017) bahwa terjadi peningkatan konsentrasi protein miofibril pada surimi ikan patin seiring dengan bertambahnya frekuensi pencucian yang ditandai dengan semakin menebalnya pita penanda protein miofibril pada pengujian SDS PAGE. Hamzah et al. (2014) menyatakan bahwa proses pencucian dapat melarutkan protein sarkoplasma, lemak, darah dan komponen pengotor lain, sehingga kadar protein miofibril di dalam surimi akan semakin meningkat.

Kekuatan gel pada surimi ikan baronang mengalami peningkatan secara nyata seiring bertambahnya frekuensi pencucian
(Tabel 2). Pencucian tiga kali mampu menghasilkan kekuatan gel tertinggi, namun nilainya tidak berbeda nyata dengan pencucian dua kali. Peningkatan kekuatan gel pada surimi ikan baronang disebabkan oleh peningkatan kadar protein larut garam pada surimi. Hassan et al. (2017) menyatakan bahwa protein larut garam khususnya miosin dan aktomiosin merupakan protein yang berperan dalam pembentukan gel surimi.

\section{Karakteristik Surimi Kering}

Hasil analisis proksimat pada surimi kering memperlihatkan bahwa kadar air menurun sedangkan kadar protein dan abu mengalami peningkatansecara nyata seiring bertambahnya suhu pengeringan, (Tabel 3). Penurunan kadar air hingga level yang rendah sangat diharapkan pada produk surimi kering karena akan membuat masa dan volume surimi semakin menurun, sehingga meningkatkan efisiensi dalam penyimpanan dan transportasi. Peningkatan kadar protein dan kadar abu tersebut disebabkan oleh menyusutnya kadar air yang terukur di dalam surimi, sehingga proporsi kadar protein dan kadar abu menjadi meningkat. Surimi kering hasil pengeringan menggunakan suhu 60 dan $70^{\circ} \mathrm{C}$ memiliki komposisi kimia sesuai dengan konsentrat protein ikan tipe B yang telah ditetapkan oleh Food and Agriculture Organization (FAO).

Perbedaan suhu pengeringan yang digunakan berpengaruh nyata terhadap derajat putih pada surimi kering yang dihasilkan (Tabel 3). Derajat putih pada surimi kering mengalami peningkatan secara nyata 
Tabel 2 Derajat putih, $\mathrm{pH}$, protein larut garam dan kekuatan gel surimi basah

(Table 2 Whiteness, $p H$, salt soluble protein and gel strenght of wet surimi)

\begin{tabular}{ccccc}
\hline $\begin{array}{c}\text { Frekuensi } \\
\text { pencucian/ } \\
\text { Washing cycle }\end{array}$ & $\begin{array}{c}\text { Derajat putih/ } \\
\text { Whiteness }\end{array}$ & $\mathrm{pH} / \mathrm{pH}$ & $\begin{array}{c}\text { Protein larut } \\
\text { garam (\%)/ } \\
\text { Myofibril (\%) }\end{array}$ & $\begin{array}{c}\text { Kekuatan gel (g.cm)/ } \\
\text { gel strenght (g.cm) }\end{array}$ \\
\hline 1 & $43.64 \pm 1.93^{\mathrm{b}}$ & $6,73 \pm 0,1^{\mathrm{b}}$ & $3,96 \pm 0,7^{\mathrm{b}}$ & $1080,20 \pm 327,45^{\mathrm{b}}$ \\
\hline 2 & $50.61 \pm 1.81^{\mathrm{a}}$ & $7,07 \pm 0,1^{\mathrm{a}}$ & $5,27 \pm 0,3^{\mathrm{a}}$ & $1387,40 \pm 100,03^{\mathrm{a}}$ \\
\hline 3 & $51.29 \pm 1.13^{\mathrm{a}}$ & $7,07 \pm 0,1^{\mathrm{a}}$ & $5,95 \pm 0,2^{\mathrm{a}}$ & $1984,10 \pm 305,83^{\mathrm{a}}$ \\
\hline
\end{tabular}

hingga suhu pengeringan $60^{\circ} \mathrm{C}$, namun pada suhu pengeringan $70^{\circ} \mathrm{C}$ terjadi penurunan terhadap derajat putih yang dihasilkan. Musa et al. (2005) menjelaskan bahwa derajat putih yang menurun diduga disebabkan oleh terjadinya reaksi pencoklatan non enzimatis yaitu adanya reaksi antar asam amino dengan gula trehalosa. Huda et al. (2000) melaporkan bahwa surimi kering dari ikan beloso (Saurida tumbil) mengalami peningkatan kecerahan (lightness) seiring bertambahnya suhu pengeringan, yaitu meningkat dari 75,5 pada pengeringan suhu $50^{\circ} \mathrm{C}$ menjadi 77,3 dan 78,8 pada pengeringan suhu $60^{\circ} \mathrm{C}$ dan $70^{\circ} \mathrm{C}$. Nilai kecerahan mengalami peningkatan seiring bertambahnya suhu pengeringan, selain itu penurunan kadar air mengakibatkan konsentrasi protein pada surimi kering meningkat, peningkatan kadar protein pada isolat protein ikan berpengaruh terhadap peningkatan nilai kecerahan (lightneess) yang dihasilkan (Kristinsson et al. 2005).

Daya ikat air atau water holding capacity didefinisikan sebagai kemampuan daging untuk mengikat atau mencegah air untuk tidak keluar dari struktur tiga dimensi protein selama mendapatkan perlakuan mekanis (pemotongan, penggilingan, pengadonan), pemasakan, penyimpanan dan thawing (Zayas 1997; Musa et al. 2005). Kemampuan daya ikat air pada surimi kering sangat berpengaruh terhadap pembentukan gel yang baik. Daya ikat air pada surimi ikan baronang mengalami penurunan secara nyata hingga suhu $60^{\circ} \mathrm{C}$ (Tabel 3). Hasil yang sama ditunjukkan oleh Huda et al. (2000) bahwa peningkatan suhu pengeringan berpengaruh terhadap penurunan daya ikat air pada surimi kering ikan beloso yang dihasilkan. Daya ikat air pada surimi kering yang semakin berkurang diduga disebabkan oleh denaturasi protein karena pengaruh peningkatan suhu pengeringan. Zayas (1997) menyatakan bahwa daya ikat air sangat dipengaruhi oleh struktur tiga dimensi dalam protein miofibril. Protein moifibril menyediakan ruangan terbuka untuk terjadinya imobilisasi air, sehingga denaturasi protein akan memberikan pengaruh terhadap pengkerutan ruangan tersebut.

Kapasitas rehidrasi juga merupakan salah satu parameter penting yang dapat digunakan untuk mengukur kualitas produk pangan. Hasil analisis menunjukkan bahwa kapasitas rehidrasi pada surimi kering meningkat nyata seiring bertambahnya suhu pengeringan (Tabel 3). Hasil ini juga sesuai dengan penelitian Nimmol et al. (2007) kapasitas rehidrasi irisan pisang mengalami peningkatan seiring bertambahnya suhu pengeringan. suhu pengeringan yang lebih tinggi dapat meningkatkan porositas struktur bahan, sehingga daya serap air menjadi lebih tinggi yang berimplikasi pada meningkatnya kapasitas rehidrasi bahan pangan kering (Andriani et al. 2013).

Densitas kamba merupakan perbandingan bobot bahan dengan volume yang ditempati, termasuk ruang kosong di antara butiran bahan pangan. Pengukuran densitas kamba sangat penting karena dapat memperhitungkan volume kemasan dan ruang penyimpanan yang akan digunakan. Hasil analisis menunjukkan bahwa suhu pengeringan berpengaruh nyata terhadap densitas kamba pada surimi kering yang dihasilkan, semakin meningkat suhu pengeringan maka semakin menurun densitas kamba yang dihasilkan. Densitas kamba terkecil dari surimi kering dihasilkan dari pengeringan surimi menggunakan suhu $60^{\circ} \mathrm{C}$ (Tabel 3). Rendahnya densitas 
Tabel 3 Komposisi proksimat surimi kering

(Table 3 Proximate composition of dried surimi)

\begin{tabular}{ccccccc}
\hline $\begin{array}{c}\text { Komposisi } \\
\text { kimia (\%)/ }\end{array}$ & \multicolumn{2}{c}{ Suhu pengeringan $\left({ }^{\circ} \mathrm{C}\right) /$ Themperature $\left({ }^{\circ} \mathrm{C}\right)$} & \multicolumn{2}{c}{$\begin{array}{c}\text { Konsentrat protein ikan }{ }^{\star} / \\
\text { Fish protein concentrate }\end{array}$} \\
\cline { 2 - 7 } $\begin{array}{c}\text { Proximate } \\
\text { composition }\end{array}$ & 40 & 50 & 60 & 70 & $\begin{array}{l}\text { Tipe A (\%)/ } \\
\text { Tipe B (\%)/ } \\
\text { Type A (\%) }\end{array}$ & Type B (\%) \\
\hline Air & $25.42 \pm 0.14^{\mathrm{a}}$ & $12.39 \pm 0.13^{\mathrm{b}}$ & $8.58 \pm 0.09^{\mathrm{c}}$ & $7.93 \pm 0.11^{\mathrm{d}}$ & $<10.0$ & $<10.0$ \\
Protein & $57.38 \pm 1.38^{\mathrm{a}}$ & $62.03 \pm 0.19^{\mathrm{b}}$ & $67.80 \pm 0.57^{\mathrm{c}}$ & $73.95 \pm 1.06^{\mathrm{d}}$ & $>80.0$ & $>80.0$ \\
Lemak & $2.32 \pm 0.48^{\mathrm{a}}$ & $2.46 \pm 0.28^{\mathrm{a}}$ & $2.71 \pm 0.30^{\mathrm{a}}$ & $2.66 \pm 0.17^{\mathrm{a}}$ & $<0.75$ & $<3.0$ \\
Abu & $1.18 \pm 0.09^{\mathrm{a}}$ & $1.43 \pm 0.05^{\mathrm{b}}$ & $1.50 \pm 0.05^{\mathrm{b}}$ & $2.44 \pm 0.05^{\mathrm{c}}$ & - & - \\
\hline
\end{tabular}

Tabel 4 Sifat fisikokimia surimi kering

(Table 4 Physicochemistry properties of dried surimi)

\begin{tabular}{ccccccc}
\hline $\begin{array}{c}\text { Suhu } \\
\text { pengeringan } \\
\left({ }^{\circ} \mathrm{C}\right) / \text { Drying } \\
\text { themperature } \\
\left({ }^{\circ} \mathrm{C}\right)\end{array}$ & $\begin{array}{c}\text { Derajat } \\
\text { putih }(\%) / \\
\text { Whiteness } \\
(\%)\end{array}$ & $\begin{array}{c}\text { Daya ikat air } \\
(\mathrm{mL} / \mathrm{g}) / \text { Water } \\
\text { holding capacity } \\
(\mathrm{mL} / \mathrm{g})\end{array}$ & $\begin{array}{c}\text { Kapasitas } \\
\text { rehidrasi }(\%) / \\
\text { Rehidration } \\
\text { capacity }(\%)\end{array}$ & $\begin{array}{c}\text { Densitas } \\
\text { kamba/ Bulk } \\
\text { density }\end{array}$ & $\begin{array}{c}\text { Stabilitas } \\
\text { emulsi/ } \\
\text { Emulsion } \\
\text { stability }\end{array}$ & $\begin{array}{c}\text { Protein } \\
\text { larut garam/ } \\
\text { Myofibril }\end{array}$ \\
\hline 40 & $46.9 \pm 0.82^{\mathrm{d}}$ & $25.10 \pm 0.63^{\mathrm{a}}$ & $2.12 \pm 0.03^{\mathrm{c}}$ & $0.57 \pm 0.01^{\mathrm{a}}$ & $5.04 \pm 0.34^{\mathrm{c}}$ & $2.84 \pm 0.18^{\mathrm{a}}$ \\
\hline 50 & $59.2 \pm 0.83^{\mathrm{b}}$ & $12.77 \pm 0.55^{\mathrm{b}}$ & $2.21 \pm 0.02^{\mathrm{c}}$ & $0.54 \pm 0.0^{\mathrm{a}}$ & $20.10 \pm 4.81^{\mathrm{b}}$ & $2.49 \pm 0.08^{\mathrm{b}}$ \\
\hline 60 & $61.9 \pm 0.08^{\mathrm{a}}$ & $8.53 \pm 0.09^{\mathrm{c}}$ & $2.79 \pm 0.10^{\mathrm{b}}$ & $0.43 \pm 0.03^{\mathrm{b}}$ & $61.09 \pm 2.59^{\mathrm{a}}$ & $1.96 \pm 0.13^{\mathrm{c}}$ \\
\hline 70 & $55.8 \pm 0.45^{\mathrm{c}}$ & $7.98 \pm 0.12^{\mathrm{c}}$ & $3.32 \pm 0.09^{\mathrm{a}}$ & $0.38 \pm 0.02^{\mathrm{b}}$ & $66.30 \pm 3.51^{\mathrm{a}}$ & $1.85 \pm 0.09^{\mathrm{c}}$ \\
\hline
\end{tabular}

kamba mengindikasikan bahwa semakin tinggi tingkat porositas suatu bahan atau ukuran dari ruang kosong di antara bahan. Diza et al. (2014) menjelaskan bahwa densitas kamba pada bahan pangan kering sangat dipengaruhi oleh kandungan air di dalamnya. Kandungan air yang semakin rendah menyebabkan bobot surimi kering menjadi berkurang, sehingga densitas kamba yang dihasilkan semakin menurun.

Stabilitas emulsi digunakan untuk mengukur keberhasilan protein sebagai emulsifier dalam kemampuannya untuk mempertahankan emulsi dari perlakuan pemanasan. Stabilitas emulsi pada surimi kering mengalami peningkatan seiring bertambahnya suhu pengeringan (Tabel 3). Suhu pengeringan $60^{\circ} \mathrm{C}$ mampu menghasilkan stabilitas emulsi terbaik pada surimi kering. Eltayeb et al. (2011) menyatakan bahwa sifat emulsi dikaitkan dengan kemampuan menjembatani air dan lemak akibat kepemilikan area hidrofobik dan hidrofilik protein. Kemampuan emulsi dipengaruhi oleh kandungan protein. Protein dapat membentuk dan menstabilkan emulsi dengan mengurangi tegangan permukaan dan tolakan elektrostatik droplet minyak.

Sifat fungsional pada protein miofibril dapat mengalami perubahan karena terjadinya denaturasi protein. Hasil analisis ragam pada surimi kering menunjukkan bahwa nilai protein larut garam (PLG) mengalami penurunan secara nyata seiring bertambahnya suhu pengeringan (Tabel 3). Penurunan kadar protein miofibril menjadi indikator dari terjadinya denaturasi protein pada surimi kering. Roongruangsri dan Bronlund (2016) menjelaskan bahwa proses pengeringan menjadi titik kritis karena protein sangat 
sensitif terhadap suhu, peningkatan suhu pemanasan dapat berakibat pada semakin terdenaturasinya protein di dalam daging.

\section{KESIMPULAN}

Frekuensi pencucian dua kali mampu menghasilkan surimi basah dengan kualitas terbaik. Pengeringan menggunakan pengering kabinet (cabinet driyng) dengan suhu $60^{\circ} \mathrm{C}$ mampu menghasilkan surimi kering dengan derajat putih yang tinggi dan karakteriktik sesuai dengan standard Konsentrat Protein Ikan tipe B.

\section{DAFTAR PUSTAKA}

Andriani M, Ananditho BK, Nurhartadi E. 2013. Pengaruh suhu pengeringan terhadap karakteristik fisik dan sensori tepung tempe bosok. Jurnal Teknologi Hasil Pertanian. 6(2): 95-102.

[AOAC] Association of Official Analytical Chemyst. 2005. Official Method of Analysis of The Association of Official Analytical of Chemist. Arlington (US): The Association of Official Analytical Chemist, Inc.

Asgharzadeh A, Shabanpour B, Aubourg SP, Hosseini H. 2010. Chemical changes in silver carp (Hypophthalmichthys molitrix) minced muscle during frozen storage: effect of a previous washing process. Grasas Y Aceites. 61(1): 95-101.

Balange AK, Benjakul S. 2009. Enhancement of gel strength of bigeye snapper (Priacanthus tayenus) surimi using oxidised phenolic compounds. Food Chemistry. 113: 61-70.

Brandl SJ, Bellwood DR. 2013. Pair formation in the herbivorous rabbitfish Siganus doliatus. Journal of Fish Biology. 82(6): 2031-2044.

Cando D, Herranz B, Borderías AJ, Moreno HM. 2015. Effect of high pressure on reduced sodium chloride surimi gels. Food Hydrocolloids. 51: 176-187.

Chaijan M, Benjakul S, Visessanguan W, Faustman C. 2004. Characteristics and gel properties of muscles from sardine (Sardinella gibbosa) and mackerel (Rastrelliger kanagurta) caught in Thailand. Food Research International. 37(10): 1021-1030.
Diza YH, Wahyuningsih T, Silfia. 2014. Penentuan waktu dan suhu pengeringan optimal terhadap sifat fisik bahan pengisi bubur kampiun instan menggunakan pengering vakum. Jurnal Litbang Industri. 4(2): 105-114.

Eltayeb ARSM, AO Ali, AA Abou-Arab, dan FM Abu-Salem. 2011. Chemical composition and functional properties of flour and protein isolate extracted from bambaragroundnut (Vigna subterranean). African Journal of Food Science. 5(2): 82-90.

Hamzah N, Sarbon NM, Amin AM. 2014. Physical properties of cobia (Rachycentron canadum) surimi: effect of washing cycle at different salt concentrations. Journal of Food Science and Technology. 6(4): 1401-1406

Hassan MA, Balange AK, Senapati SR, Xavier KA. 2017. Effect of different washing cycles on the quality of Pangasius hypophthalmus surimi. Fishery Technology. 54: 51-59.

Hosseini-Shekarabi SP, Hosseini SE, Soltani M, Kamali A, Valinassab T. 2014. A comparative study on physicochemical and sensory characteristics of minced fish and surimi from black mouth croaker (Atrobucca nibe). Journal of Agricultural Sciences Technology. 16: 1289-1300.

Huda N, Abdullah A, Babji AS. 2001. Functional properties of surimi powder from three Malaysian marine fish. International Journal of Food Science and Technology. 36(4): 401-406.

Huda N, Santana P, Abdullah R, Yang TA. 2012. Effect of different dryoprotectant on funtional properties of thredfin bream surimi powder. Journal of Fish Aquatic Science. 7(3): 215-223.

Ismail I, Huda N, Ariffin F, Ismail N. 2010. Effect of washing on the functional properties of duck meat. International Journal of Poultry Science. 9(6): 556-561.

Jaikumar M. 2012. A review on biology and aquaculture potential of rabbit fish in Tamilnadu (Siganus canaliculatus). International Journal of Plant, Animal and Environmental Sciences. 2(2): 57-64. 
Kang GH, Kim SH, Kim JH, Kang HK, Kim DW, Na JC, Yu DJ, Suh OS, Cchoij Y H. 2009. Effects of washing methods on gel properties of chicken surimi prepared from spent hen breast muscle. Poultry Science. 88: 1438-1443.

Karthikeyan M, Dileep AO, Shamasundar BA. 2006. Effect of water washing on the functional and rheological properties of proteins from threadfin bream (Nemipterus japonicus) meat. International Journal of Food Science and Technology. 41: 1002-1010.

Kristinsson HG, Theodore AE, Demir N Ingadottir B. 2005. A comparative study between acid and alkaliadded processing and surimi processing for the recovery of proteins from channel cat fish muscle. Journal of Food Science. 70(4): 98-306.

Lanier TC. 1986. Functional properties of surimi. Food Technology. 3: 107-114.

Lanier TC. Yongsawatdigul J. \& CarvajalRondanelli P. 2014. Surimi and surimi seafood. Boca Raton: CRC Press. Taylor \& Francis Group.

McCord A, Smyth AB, O’Neill EE. 1998. Heatinduced gelation properties of salt soluble muscle proteins as affected by nonmeat proteins. Journal of Food Science. 63(4): 580-583.

Musa KH, Aminah A, Wan-Aida WM. 2005. Functional properties of surimi related to drying methods. Malaysian Applied Biology. 34(2): 83-87.

Nimmol C, Devahastin S, Swasdisevi T, Soponronnarit S. 2007. Drying of banana slices using combined low-pressure superheated steam and far-infrared radiation. Journal of Food Engineering. 81: 624-633.

Nopianti R, Nurul H, Noryati I. 2011. A Review of the loss of the functional properties of protein during frozen storage and the improvement of gel forming properties of surimi. Journal of Food Technology. 6(1): 19-30.

Park JW. 2014. Surimi and Surimi Seafood: Third Edition. New York (US): CRC Press.

Ramadhan W, Santoso J, Trilaksani W. 2014.
Pengaruh defatting, frekuensi pencucian dan jenis dryoprotectant terhadap mutu tepung surimi ikan lele kering beku. Jurnal Teknologi Industri Pangan. 25(1): 47-56.

Roongruangsri W, Bronlund JE. 2016. Effect of air-drying temperature on physicochemical, powder properties and sorption characteristics of pumpkin powders. International Food Research Journal. 23(3): 962-972

Santana P, Huda N, Yang TA. 2012. Technology for production of surimi powder and potential of applications. International Food Research Journal. 19(4): 1313-1323.

Suvanich V, Jahncke ML, Marshal DL. 2000. Changes in selected chemical quality characteristics of channel catfish frame mince during chill and frozen storage. Journal of Food Science. 65(1): 2000.

Suzuki T. 1981. Fish dan Krill Protein in Processing Technology. London (UK): Applied Science Publishing Ltd.

Tanuja S, Viji P, Zynudheen AA, NinanG, Joshy CG. 2014. Composition, textural quality and gel strength of surimi prepared from striped catfish (Pangasianodon hypophthalmus, Souvage, 1878). Fishery Technology. 51: 106-111

Uju, Maryana F, Santoso J. 2007. Pemanfaatan refined carrageenan sebagai cryoprotectant pada penyimpanan beku surimi ikan nila. Buletin Teknologi Hasil Perikanan. 10(2): 48-59.

Uju, Nitibaskara R, Ibrahim B. Pengaruh frekuensi pencucian surimi terhadap mutu produk bakso ikan jangilus (Istiophorus sp.). Buletin Teknologi Hasil Perikanan. 8(11): 1-10.

Venugopal V, Chawla SP, Nair PM. 1996. Spray dried protein powder from threadfin bream: preparation, properties and comparison with FPC type-B. Journal of Muscle Food. 7: 55-71.

Wahyuningtyas LA, Nurilmala $M$, Sondita MFA, Taurusman AA, Sudrajat AO. 2017. Nutritional profile of Rabbitfish (Siganus spp.) from the Kepulauan Seribu (Thousand Islands), Jakarta, Indonesia. International Food Research Journal. 24(2): 685-690. 
Wijayanti I, Surti T, Agustini TW, Darmanto YS. 2014. Perubahan asam amino surimi ikan lele dengan frekuensi pencucian yang berbeda. Jurnal Pengolahan Hasil Perikanan Indonesia. 17(1): 29-41.

Xu Y, Zhang M, Tu D, Sun J, Zhou L, Mujumdar AS. 2004. A two-stage convective air and vacuum freeze-drying technique for bamboo shoots. International Journal of Food Science and Technology. 40(6): 589-595.
Yatsumatsu K, Sawada K, Moritaka S, Misaki M, Toda J, Wada T, Ishi K. 1972. Whipping and emulsifying properties of soybean products. Agricultural Biology and Chemistry. 36(5): 719-727.

Zayas JF. 1997. Functional of Protein in Foods. Berlin (GR): Springer-Verlag Heidelberg. 